\title{
PENGARUH PENAMBAHAN MATERIAL SPIRO-TAD DAN SPIRO-TPD SEBAGAI HOLE TRANSPORT MATERIAL PADA KARAKTERISTIK DSSC
}

\author{
LUSI SAFRIANI *, WINNA PRASITA PRIMAWATI, EUIS SITI NURAZIZAH, CUKUP \\ MULYANA, ANNISA APRILIA \\ Departemen Fisika Fakultas MIPA Universitas Padjadjaran, \\ Jl. Raya Bandung-Sumedang Km 21, Jatinangor 45363 \\ *email: lusi.safriani@phys.unpad.ac.id
}

\begin{abstract}
Abstrak. Dye sensitized solar cells atau DSSC merupakan sel surya yang sedang dikembangkan karena memiliki beberapa kelebihan yaitu biaya fabrikasi yang murah, proses fabrikasi sederhana dan dapat dioperasikan pada intensitas cahaya yang rendah. Akan tetapi, efisiensi DSSC masih jauh lebih rendah dibandingkan sel surya berbasis silikon. Salah satu upaya untuk meningkatkan efisiensi DSSC adalah dengan menambahkan lapisan Hole Transport Material (HTM) untuk membantu proses difusi dan transport muatan sehingga didapatkan efisiensi yang lebih baik. Material spiro merupakan material yang memiliki stabilitas yang baik sehingga cocok untuk dijadikan sebagai HTM pada divais sel surya. Dua di antara contoh material spiro adalah SpiroTAD dan Spiro-TPD. Keduanya memiliki nilai mobilitas hole yang cukup baik. Dalam penelitian ini, DSSC dengan struktur $\mathrm{FTO} / \mathrm{TiO}_{2} /$ dye-Ru/HTM/mosalyte/Pt/FTO telah berhasil difabrikasi. Selain itu dilakukan pula proses pemanasan sebelum proses perendaman dye-Ru dilakukan dengan tujuan menghilangkan molekul oksigen yang terperangkap pada lapisan mesopori $\mathrm{TiO}_{2}$. Hasil pengukuran rapat arus dan tegangan ( $\mathrm{J}$ V) menunjukkan bahwa Power Conversion Efficiency (PCE) tertinggi didapatkan dari DSSC dengan HTM Spiro-TPD yaitu sebesar 2,94\%.
\end{abstract}

Kata kunci: DSSC, HTM, Spiro-TAD, Spiro TPD, PCE

\begin{abstract}
Dye sensitized solar cells or DSSC are solar cells that are being developed because they have several advantages. It has a low-cost fabrication, simple fabrication processes and can be operated at low light intensity. However, DSSC efficiency is still far lower than silicon-based solar cells. An effort to improve DSSC efficiency is to add a Hole Transport Material (HTM) layer to facilitate the diffusion and transport of charges, so that better efficiency could be obtained. Spiro material is a material that has good stability and it is suitable to be used as HTM in solar cell devices. Two of the examples of spiro-material are Spiro-TAD and Spiro-TPD which have good hole mobility value. In this study, DSSC with the structure of $\mathrm{FTO} / \mathrm{TiO}_{2} / \mathrm{dye}^{\mathrm{Ru}} / \mathrm{HTM} / \mathrm{mosalyte}_{\mathrm{Pt}} / \mathrm{FTO}$ has been successfully fabricated. Moreover, the heating process that was done before the dye$\mathrm{Ru}$ immersion process was carried out to remove oxygen molecules trapped in the mesoporous layer of $\mathrm{TiO}_{2}$. The measurement results of current density and voltage $(\mathrm{J}-\mathrm{V})$ shows that the highest Power Conversion Efficiency (PCE) at $2.94 \%$ is obtained from DSSC with HTM Spiro-TPD.
\end{abstract}

Keywords: DSSC, HTM, Spiro-TAD, Spiro TPD, PCE

\section{Pendahuluan}

Akhir-akhir ini kebutuhan energi bertambah secara signifikan yang mengakibatkan berbagai masalah khususnya yang berkaitan dengan ketersediaan energi. Sumber energi konvensional yang berasal dari fosil seperti minyak bumi, gas bumi dan 
batubara akan semakin berkurang sehingga diperlukan sumber energi baru yang kemudian dikenal sebagai energi baru dan terbarukan (renewable energy). Dari berbagai sumber energi baru dan terbarukan seperti angin, biomassa ataupun hydropower, penggunaan energi yang berasal dari matahari merupakan alternatif sumber energi yang paling potensial. Hal ini disebabkan karena Indonesia mempunyai potensi energi matahari yang cukup besar.

Sel surya merupakan perangkat yang dapat mengkonversi energi matahari menjadi energi listrik. Sel surya menjadi salah satu sumber energi terbarukan yang dapat memecahkan masalah ketersediaan energi [1]. Sel surya memiliki berbagai jenis dan salah satu sel surya yang telah tersedia secara komersil adalah sel surya berbasis teknologi silicon [2]. Namun, harga produksi yang mahal dibanding sumber energi fosil dan efisiensi yang rendah menyebabkan sel surya sulit menjadi sumber energi utama menggantikan sumber energi fosil. Untuk mengatasi masalah tersebut dibutuhkan material baru dengan harga yang murah, proses fabrikasi yang mudah, namun dapat menghasilkan efisiensi sel surya yang lebih baik.

Salah satu jenis sel surya yang menarik banyak perhatian adalah sel surya yang dikembangkan oleh Grätzel [3]. Sel surya ini sering juga disebut dengan sel Grätzel atau Dye Sensitized Solar Cells (DSSC) yaitu sel surya tersensitisasi dye. Prinsip kerja DSSC berbeda dengan sel surya konvensional/sel surya berbasis teknologi silicon (inorganic solar cell). Prinsip kerja DSSC berdasarkan proses fotosintesis. Sama halnya dengan peran klorofil pada tumbuhan, molekul dye (sensitizers) mengabsorb cahaya sehingga menghasilkan muatan positif dan negatif [4]. DSSC adalah salah satu kandidat potensial sel surya generasi yang akan datang, hal ini disebabkan tidak diperlukannya material yang punya kemurnian tinggi sehingga biaya produksi yang diperlukan juga relatif rendah. Meskipun murah, sistem ini mampu menghasilkan efisiensi konversi sinar menjadi listrik sekitar 11,1\%, tingkat efisiensi yang tidak mudah untuk dicapai sejak konsep ini pertama kali dicetuskan awal tahun 1970 [5]. Meskipun efisiensinya cukup tinggi, pengembangan sel surya ini masih memiliki kelemahan yaitu pada kestabilan sistem. Efisiensi dan kestabilan DSSC dipengaruhi oleh ketiga komponen penyusunnya yaitu (i) lapisan tipis semikonduktor $\mathrm{TiO}_{2}$ dan material $d y e$ yang pada umumnya digunakan kompleks ruthenium (II) sebagai sensitizer, (ii) elektroda lawan Pt dan (iii) larutan elektrolit yang merupakan pasangan redoks. Fotodegradasi sensitizer dan penguapan larutan elektrolit cair merupakan penyebab utama terhadap rendahnya kestabilan DSSC [6]. Keberadaan larutan elektrolit cair juga membuat proses pembuatan sel surya ini menjadi sulit.

Untuk mengatasi masalah kestabilan dan kesulitan fabrikasi DSSC dengan elektrolit cair, beberapa peneliti menggunakan elektrolit dari material padat [7]. Hal ini dilakukan dengan memodifikasi struktur DSSC melalui penambahan lapisan yang selain berfungsi sebagai lapisan pembawa elektron (Electron Transport Material/ETM) maupun lapisan pembawa hole (Hole Transport Material/HTM) juga berfungsi sebagai media untuk terjadinya proses pasangan reduksi-oksidasi (redoks).

HTM merupakan material yang membantu proses difusi muatan positif/hole sehingga mempermudah proses transport hole dan sekaligus mencegah terjadinya proses rekombinasi elektron-hole pada lapisan dye. Material spiro merupakan material yang memiliki stabilitas yang baik sehingga cocok untuk dijadikan HTM pada DSSC [8]. Dua di antara contoh material spiro adalah Spiro-TAD (2,2',7,7'tetrakis-(diphenylamino)-9,9'-spirobifluorene) dan Spiro-TPD (N,N'- Bis-(3- 
methylphenyl)-N,N'-bis(phenyl)-9,9'-spirobifluorene). Kedua material tersebut memiliki beberapa karakteristik yang sangat baik untuk dijadikan HTM, yaitu memiliki suhu transisi gelas $\left(\mathrm{T}_{\mathrm{g}}\right)$ yang tinggi dengan struktur amorf dan massa molar molekul yang rendah (small molecule). Selain itu, material spiro-TAD dan spiro-TPD merupakan material spiro berbasis gugus arylamines sehingga memiliki daerah absorbansi pada rentang panjang gelombang ultraviolet (UV) [8].

Dalam penelitian ini telah dilakukan fabrikasi DSSC dengan penambahan HTM Spiro-TAD dan Spiro-TPD dengan struktur FTO/TiO $2 /$ dye/HTM/mosalyte/Pt/FTO. Proses perendaman dye-Ruthenium dilakukan dengan dua cara berbeda, yaitu tanpa diawali pemanasan lapisan $\mathrm{TiO}_{2}$ dan dilakukan pemanasan lapisan $\mathrm{TiO}_{2}$ pada suhu $70^{\circ} \mathrm{C}$ dengan tujuan menghilangkan molekul-molekul oksigen yang terperangkap pada lapisan mesopori $\mathrm{TiO}_{2}$ sehingga dapat meningkatkan daya serap dye Ruthenium. Kinerja DSSC ditentukan dari hasil pengukuran rapat arus-tegangan (JV) dan dari parameter divais dapat dihitung Power Conversion Efficiency (PCE).

\section{Metode Penelitian}

Proses pembuatan sel surya dibagi menjadi 2 tahap yaitu pembuatan fotoanoda dan proses perakitan. Fotoanoda adalah bagian dari DSSC yang terbuat dari material semikonduktor oksida seperti $\mathrm{TiO}_{2}$ ataupun $\mathrm{ZnO}$. Dalam penelitian ini digunakan material mesopori $\mathrm{TiO}_{2}$. Proses pembuatan lapisan mesopori $\mathrm{TiO}_{2}$ dilakukan dengan teknik screen printing pasta $\mathrm{TiO}_{2}$ T/SP (Solaronix) pada substrat FTO (Fluorine-doped Tin Oxide), dilanjutkan dengan deposisi pasta $\mathrm{TiO}_{2} \mathrm{MC} / \mathrm{SP}$ kemudian yang dilakukan dengan proses pemanasan sampai suhu $500^{\circ} \mathrm{C}$ selama 30 menit untuk menghasilkan lapisan $\mathrm{TiO}_{2}$ yang memiliki fasa anatase. Selanjutnya $\mathrm{FTO} / \mathrm{TiO}_{2}$ direndam dalam larutan dye jenis Ruthenium N719/dye-Ru (Solaronix) selama semalam. Proses perendaman $d y e-R u$ dilakukan dengan dua cara berbeda, yaitu tanpa diawali pemanasan fotoanoda $\mathrm{FTO} / \mathrm{TiO}_{2}$ dan dilakukan pemanasan fotoanoda $\mathrm{FTO} / \mathrm{TiO}_{2}$ pada suhu $70^{\circ} \mathrm{C}$. Setelah proses perendaman selesai, fotoanoda diangkat dan dibilas dengan acetronitrile untuk menghilangkan sisa partikel dye yang tidak dapat diserap oleh lapisan $\mathrm{TiO}_{2}$. Lapisan HTM Spiro-TAD dan Spiro-TPD kemudian dideposisikan pada fotoanoda $\mathrm{FTO} / \mathrm{TiO}_{2} / d y e-R u$ dengan teknik spin-coating.

Tahap berikutnya adalah proses perakitan DSSC yang dimulai dengan dengan melapiskan surlyn (Solaronix) yang memiliki ketebalan $25 \mu \mathrm{m}$ sebagai pemisah antara fotoanoda dan elektroda lawan. Platina $(\mathrm{Pt})$ yang terdeposisi pada substrat FTO (Solaronix) digunakan sebagai elektroda lawan. Pada penelitian ini tetap digunakan elektrolit cair mosalyte (Solaronix) untuk tetap menjamin terjadinya proses redoks yang akan menghasilkan elektron dan didifusikan ke lapisan $d y e-R u$. Elektrolit mosalyte selanjutnya diinjeksikan melalui lubang yang terdapat pada elektroda lawan dengan suntikan khusus, setelah elektrolit diinjeksikan kemudian lubang ditutup dengan tape bening. Struktur DSSC yang dihasilkan yaitu adalah $\mathrm{FTO} / \mathrm{TiO}_{2} /$ dye-Ru/Spiro-TAD/Mosalyte/Pt/FTO dan $\mathrm{FTO} / \mathrm{TiO}_{2} /$ dye-Ru/SpiroTPD/Mosalyte/Pt/ FTO.

Karakterisasi yang dilakukan yaitu pengukuran spektroskopi UV-Vis pada lapisan $\mathrm{TiO} 2 / d y e-R u, \mathrm{TiO} 2 / d y e-R u / S p i r o-T A D$, dan TiO2/dye-Ru/Spiro-TPD untuk mengetahui daerah absorbansi dari masing-masing kombinasi lapisan tersebut. Kinerja DSSC dilakukan melalui pengukuran rapat arus-tegangan (J-V) 
menggunakan sumber lampu LED dengan intenstitas daya yang dipancarkan sebesar $36,5 \mathrm{~mW} / \mathrm{cm}^{2}$.

\section{Hasil dan Pembahasan}

Hasil pengukuran spektrum UV-Vis untuk lapisan $\mathrm{TiO}_{2}$, dye-Ru dalam pelarut ethanol dan lapisan $\mathrm{TiO}_{2} / d y e-R u$ diperlihatkan pada Gambar 1. Untuk melihat keberhasilan dye-Ru mensensitasi $\mathrm{TiO}_{2}$ dilihat dari pergeseran merah (bathochromic) pada pola serapan elektronik lapisanTiO $\mathrm{T}_{2} /$ dye-Ru pada daerah cahaya tampak. Hasil diperoleh sesuai dengan yang dilakukan oleh Garcia dkk [9]. Sensitasi lapisan $\mathrm{TiO}_{2}$ bertujuan untuk meningkatkan sensitifitas semikonduktor $\mathrm{TiO}_{2}$ terhadap cahaya visible. Respon terhadap cahaya visible meningkat yang ditunjukkan dengan adanya pergeseran merah yang disebabkan terjadinya proses transfer elektron dari keadaan tereksitasi $d y e-R u$ menuju pita konduksi $\mathrm{TiO}_{2}$.

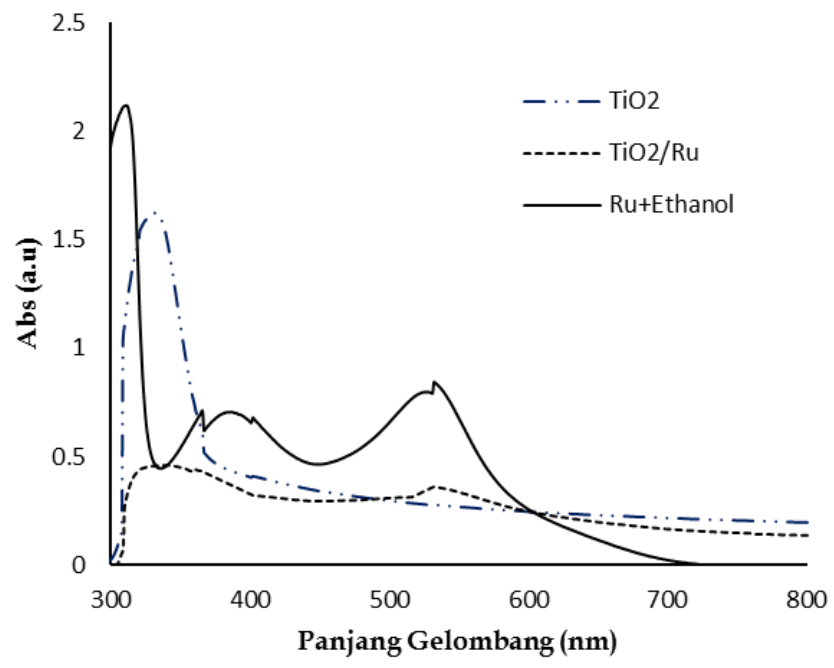

Gambar 1. Spektrum absorbansi dari lapisan $\mathrm{TiO}_{2}$, larutan dye-Ru dan lapisan $\mathrm{TiO}_{2} / d y e-\mathrm{Ru}$.

Adanya pergeseran merah (bathochromic) berkaitan pula dengan penurunan intensitas penyerapan cahaya. Penurunan intensitas penyerapan cahaya disebabkan karena perbedaan $\lambda_{\text {maks }}$ dari $\mathrm{TiO}_{2}$ dan dye-Ru. $\mathrm{TiO}_{2}$ menyerap pada panjang gelombang maksimum $327 \mathrm{~nm}$ dengan intensitas penyerapan cahayanya 1.6 a.u. sedangkan $d y e-R u$ dengan pelarut ethanol menyerap pada panjang gelombang maksimum $310 \mathrm{~nm}$ yang mengakibatkan intensitas absorbansi pun menurun (Hypochromic effect).

Gambar 2 memperlihatkan spektrum absorbansi fotoanoda tanpa HTM dan dengan penambahan HTM Spiro-TPD dan Spiro-TAD. Penambahan HTM pada fotonoada menyebabkan tingkat penyerapan cahaya atau intensitas absorbansinya meningkat. Intensitas absorbansi fotoanoda dengan penambahan HTM Spiro-TAD lebih tinggi dibandingkan dengan intensitas absorbansi fotoanoda dengan penambahan HTM Spiro-TPD. Hal ini terjadi karena struktur molekul Spiro-TAD mempunyai energi ikat yang lebih besar dibandingkan dengan energi ikat molekul Spiro-TPD. Energi ikat yang besar akan mempengaruhi intensitas absorbansi yang dihasilkan karena semakin besar energi ikat maka semakin rapat pula elektronnya, sehingga semakin banyak cahaya yang diserap. 


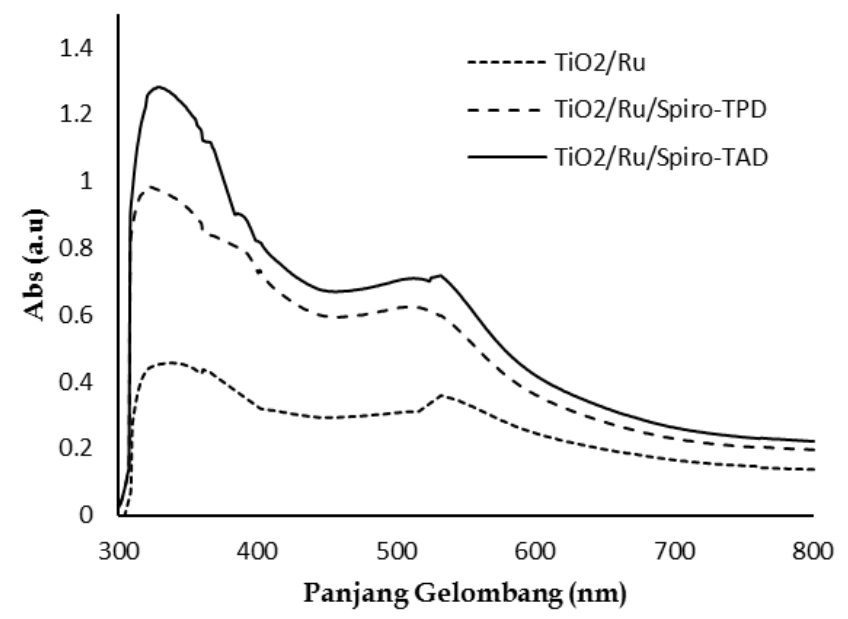

Gambar 2. Spektrum absorbansi fotoanoda tanpa HTM dan dengan penambahan HTM SpiroTPD dan Spiro-TAD.

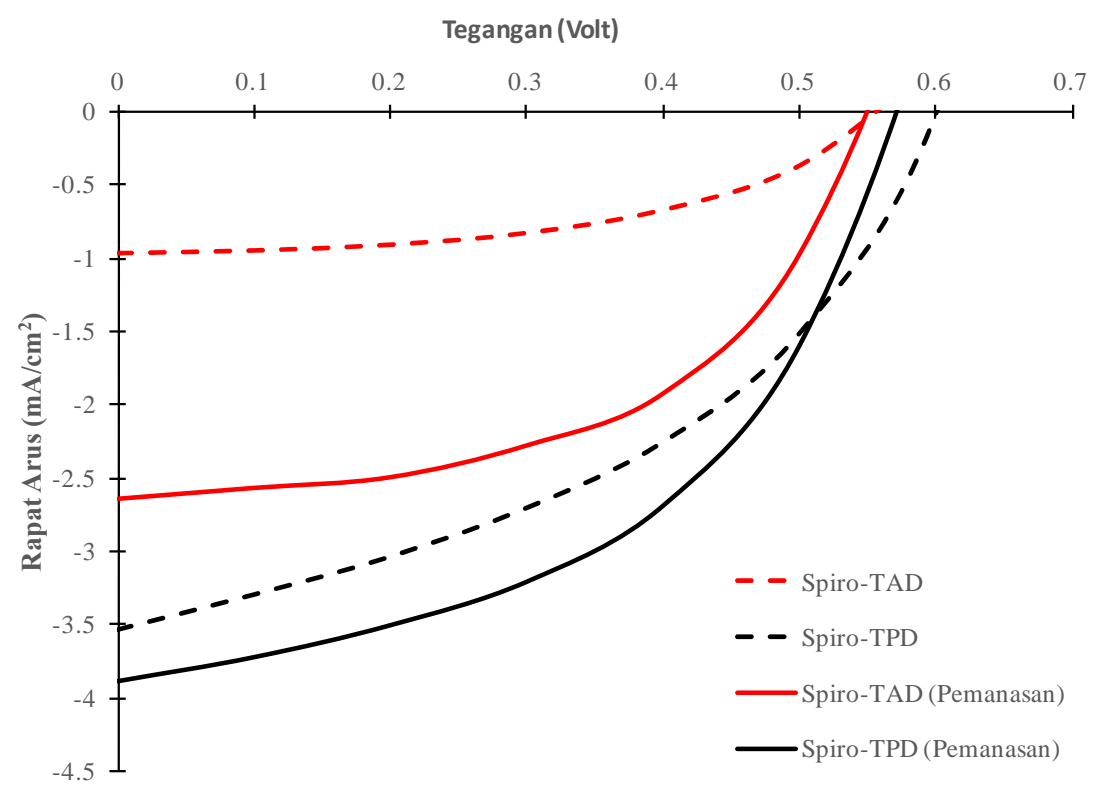

Gambar 3. Kurva J-V DSSC dengan penambahan HTM Spiro-TAD dan Spiro-TPD.

Hasil pengukuran J-V DSSC dengan penambahan lapisan Spiro-TAD dan SpiroTPD sebagai HTM diperlihatkan pada Gambar 3. Kurva J-V diperoleh dari DSSC dengan proses perendaman $d y e-R u$ yang diawali tanpa dan dengan proses pemanasan fotoanoda $\mathrm{FTO} / \mathrm{TiO}_{2}$. Parameter DSSC yaitu $\mathrm{J}_{\mathrm{SC}}, \mathrm{V}_{\mathrm{OC}}$, fill factor $(F F)$ dan efisiensi $\eta$ diperlihatkan pada Tabel 1 .

Nilai $\mathrm{V}_{\mathrm{OC}}$ yang dihasilkan dari keempat DSSC memiliki nilai yang tidak jauh berbeda, yaitu pada rentang tegangan 0,55 Volt sampai dengan 0,60 Volt. Nilai $V_{O C}$ yang sedikit lebih rendah dari nilai $\mathrm{V}_{\mathrm{OC}}$ yang diperoleh oleh kelompok peneliti lain [10] kemungkinan disebabkan adanya proses rekombinasi elektron dan hole pada lapisan fotoanoda. Nilai $\mathrm{J}_{\mathrm{SC}}$ tertinggi yaitu sebesar $3,88 \mathrm{~mA} / \mathrm{cm}^{2}$, diperoleh dari DSSC dengan HTM Spiro-TPD yang mendapatkan perlakuan panas sebelum proses perendaman $d y e-R u$. Pada DSSC tersebut $F F$ dan PCE $\eta$ yang dihasilkan masing- 
masing yaitu 0.45 dan $2,94 \%$. Nilai $\mathrm{J}_{\mathrm{SC}}$ yang dihasilkan mempengaruhi besar efisiensi divais, semakin besar $\mathrm{J}_{\mathrm{SC}}$, maka efisiensinya akan semakin besar pula. Nilai $\mathrm{V}_{\mathrm{OC}}$ dan $\mathrm{J}_{\mathrm{SC}}$ juga mempengaruhi nilai $F F$, yaitu menunjukkan keseimbangan mobilitas pembawa muatan elektron yang menuju anoda dan muatan hole yang menuju ke katoda. Semakin mendekati nilai 1 maka kinerja divais semakin baik.

Tabel 1. Parameter DSSC dengan penambahan HTM Spiro-TAD dan Spiro-TPD

\begin{tabular}{ccccc}
\hline HTM & $\begin{array}{c}\mathrm{J}_{\mathrm{SC}} \\
\left(\mathrm{mA} / \mathrm{cm}^{2}\right)\end{array}$ & $\begin{array}{c}\mathrm{V}_{\mathrm{OC}} \\
(\mathrm{Volt})\end{array}$ & $\begin{array}{c}\text { Fill Factor } \\
(\text { FF })\end{array}$ & $\begin{array}{c}\text { Efisiensi } \eta \\
(\%)\end{array}$ \\
\hline Spiro-TAD & 0,96 & 0,55 & 0,44 & 0,74 \\
Spiro-TPD & 3,52 & 0,60 & 0,39 & 2,47 \\
Spiro-TAD (Pemanasan) & 2,64 & 0,55 & 0,31 & 1,34 \\
Spiro-TPD (Pemanasan) & 3,88 & 0,57 & 0,45 & 2,94 \\
\hline
\end{tabular}

DSSC dengan penambahan HTM Spiro-TPD memiliki nilai $\mathrm{J}_{\mathrm{SC}}$ yang lebih besar baik ketika proses perendaman $d y e-R u$ diawali dengan pemanasan maupun tidak. Hal ini terjadi karena selain Spiro-TPD memiliki mobilitas hole yang lebih besar dibanding Spiro-TAD juga terjadi karena tingkat energi LUMO dari Spiro-TPD lebih negatif dibanding tingkat energi LUMO Spiro-TAD [11].

Jika dibandingkan antara DSSC tanpa pemanasan fotoanoda $\mathrm{FTO} / \mathrm{TiO}_{2}$ dan dengan pemanasan fotoanoda $\mathrm{FTO} / \mathrm{TiO}_{2}$, divais dengan pemanasan menghasilkan $\mathrm{J}_{\mathrm{SC}}$ yang lebih baik. Hal ini terjadi karena dengan pemanasan fotoanoda $\mathrm{FTO} / \mathrm{TiO}_{2}$ gelembung-gelembung oksigen yang terperangkap di dalam lapisan fotoanoda $\mathrm{TiO}_{2}$ dapat hilang, tidak menghalangi penetrasi $d y e-R u$ ke dalam lapisan mesopori $\mathrm{TiO}_{2}$ sehingga meningkatkan jumlah $d y e-R u$ yang ada dalam lapisan mesopori $\mathrm{TiO}_{2}$.

\section{Kesimpulan}

DSSC dengan penambahan HTM berupa material Spiro-TPD dan Spiro-TAD telah berhasil difabrikasi. Hasil pengukuran spektrum UV-Vis menunjukkan bahwa penambahan HTM berbasis material Spiro meningkatkan absorbansi pada rentang panjang gelombang ultraviolet (UV) yang berasal dari gugus arylamines. Proses pemanasan fotoanoda $\mathrm{FTO} / \mathrm{TiO}_{2}$ sebelum perendaman dye-Ru merupakan cara yang cukup efektif untuk meningkatkan penetrasi $d y e-R u$ ke dalam lapisan mesopori $\mathrm{TiO}_{2}$. Divais dengan HTM Spiro-TPD yang dibuat melalui proses pemanasan fotoanoda sebelum perendaman dye-Ru menunjukkan kinerja paling baik dengan $\mathrm{J}_{\mathrm{SC}}$ sebesar $3,88 \mathrm{~mA} / \mathrm{cm}^{2}$ dan efisiensi divais $2,94 \%$.

\section{DaftarPustaka}

1. E. Kabir, P. Kumar, S. Kumar, A. Adelodun, and K. H. Kim. Solar energy: Potential and future prospects. Renewable and Sustainable Energy Reviews, Vol. 82 (2017) p 894-900.

2. D. Neuhaus and M. Adolf. Industrial Silicon Wafer Solar Cells. Advances in Optoelectronics, Vol. 2007 (2008) p. 24521.

3. B. O'Regan and M. Grätzel. A low-cost, high-efficiency solar cell based on dyesensitized colloidal $\mathrm{TiO}_{2}$ films. Nature Vol. 353 (1991) p. 737-740. 
4. Y. Koyama, T. Miki, X. F. Wang and H. Nagae. Dye-sensitized solar cells based on the principles and materials of photosynthesis: mechanisms of suppression and enhancement of photocurrent and conversion efficiency. Int $\mathbf{J}$ Mol Sci. Vol 10 No. 11 (2009) p. 4575-4622.

5. Y. Chiba, A. Islam, Y. Watanabe, R. Komiya, N. Koide and L. Han. DyeSensitized Solar Cells with Conversion Efficiency of 11.1\%. Japanese Journal of Applied Physics, Vol. 45 (2006) p. L638-L640.

6. Umer Mehmood, Saleem-ur Rahman, Khalil Harrabi, Ibnelwaleed A. Hussein and B. V. S. Reddy. Recent Advances in Dye Sensitized Solar Cells. Advances in Materials Science and Engineering (2014) p. 974782.

7. Y. Cao, Y. Saygili, A. Ummadisingu et al. $11 \%$ efficiency solid-state dyesensitized solar cells with copper(II/I) hole transport materials. Nat. Commun. Vol. 8 (2017), p. 15390.

8. T. P. I. Saragi, T. Spehr, A. Siebert, T. Fuhrmann-Lieker, and J. Salbeck. Spiro Compounds for Organic Optoelectronics. Chem. Rev. Vol. 107 (2007) p. 1011-1065.

9. C. Garcia, A. Polo and N. Iha. Fruit extracts and ruthenium polypyridinic dyes for sensitization of $\mathrm{TiO}_{2}$ in photoelectrochemical solar cells. Journal of Photochemistry and Photobiology a Chemistry Vol. 160 No. 1 (2003). p. 8791.

10. Jong Tae Kim, Su Kyung Park, Cheon Su Kang, Wook Hyun Kim and Yoon Soo Han. Improved Open-Circuit Voltage of Dye-Sensitized Solar Cells with LiNO3-Incorporated Titanium Dioxides. Journal Molecular Crystals and Liquid Crystals Vol. 586 No. 1(2013). p. 23-32.

11. T. P. I. Saragi, T. Fuhrmann-Lieker and J. Salbeck. Comparison of ChargeCarrier Transport in Thin Films of Spiro-Linked Compounds and Their Corresponding Parent Compounds. Adv. Funct. Mater. 16 (2006) p. 966-974. 